\title{
PERFORMANCE EVALUATION IN ISO 9001:2015
}

\author{
Radosław WOLNIAK \\ Politechnika Śląska, Wydział Organizacji i Zarządzania, Instytut Ekonomii i Informatyki; rwolniak@polsl.pl, \\ ORCID: 0000-0003-0317-9811
}

Purpose: The aim of the paper is to analyze the problems connected with the performance evaluation realized within the organization in the ISO 9001:2015 implementation process.

Design/methodology/approach: Critical literature analysis. Analysis of international literature from main databases and polish literature and legal acts connecting with researched topic.

Findings: The organization shall evaluate the performance and the effectiveness of the quality management system. it should retain appropriate documented information as evidence of the results. To achieve good performance evolution level in organization which have ISO 9001:2015 quality management system we need to implement appropriate monitoring system. Especially useful system is a system based on KPIs indicators which can measure particular activities of the organization. If we use good and broad system of KPIs indicator we can measure almost all aspect of functioning of quality management system. Then we could use those measure in the process of quality management system improvement. It lead to better performance of the system, better quality and better customer satisfaction.

Originality/value: Detailed analysis of all subjects related to performance evaluation in ISO 9001:2015.

Keywords: quality management, ISO 9001:2015, ISO 9001, performance, KPI.

Category of the paper: literature review.

\section{Introduction}

The using of quality management system is now widely widespread in almost all counties (ISO 9001:2015; Chen et al., 2016; Cholewicka-Goździk, 2016; Łagowski, and Żuchowski, 2016; Wolniak, and Hąbek, 2015; Wolniak, and Skonicka-Zasadzień, 2010; Wolniak, and Sułkowski, 2015; Wolniak, 2020). New version of implemented standards need the impelemntation of performance evaluation processes (Hillson, 2001; Gębczyńska, and Wolniak, 2018; Juszczak-Wiśniewska, and Ligarski, 2015, 2016; Łuczak, and Wolniak, 2016; Sułkowski, and Wolniak, 2016, 2018; Szczucka-Lasota, and Wolniak, 2018). This evaluation is widely used in organization to achieve the increase of effectiveness of quality management 
system implemented in particular organization (Horodecka, and Wolniak, 2015; Pacana, 2014; Pacana et al., 2014, 2017; Pacana, and Stadnicka, 2006, 2017; Wolniak, 2011; Wolniak, and Sułkowski, 2015; Wolniak, and Sułkowski, 2016; Wolniak et al., 2019; Wolniak and SkotnickaZasadzień, 2008, 2011, 2019; Novakova, et al., 2016; Stawiarska, et al., 2020).

The organization shall evaluate the performance and the effectiveness of the quality management system. it should retain appropriate documented information as evidence of the results.

The aim of the paper is to analyze the problems connected with the performance evaluation realized within the organization in the ISO 9001:2015 implementation process.

\section{The scope of performance evaluation}

To do a proper performance evaluation the organization shall to determine (ISO 9001:2015; Ząbek, 2016):

- what needs to be monitored and measured;

- the methods for monitoring, measurement, analysis and evaluation needed to ensure valid results;

- when the monitoring and measuring shall be performed;

- when the results from monitoring and measurement shall be analyzed and evaluated.

The processes of the quality management system should be improved. The main processes under improvement are (Natarajan, 2017; Egonsson et al., 2013):

- General requirements.

- Nonconformity and corrective action.

- Continual improvement.

Evaluating the customer's performance firstly the organization should to measure the customer satisfaction (Pokosińska et al., 2002; Szkiel, 2016; Żemigła, 2017). The organization shall determine the methods for obtaining, monitoring and reviewing this.

We can define customer satisfaction as (Wolniak, 2018; Hoyle, 2009; Montgomery, 2009):

- customer satisfaction measure how well the expectation of a customer concerning a product or service provided by company have been met,

- the degree of satisfaction provided by the goods or services of a company as measured by the number of repeat customers,

- a feeling of satisfaction felt by customer with a product or service obtained from a business, 
- customer satisfaction indicates the fulfillment that customers derive from doing business with a firm. In other words, it's how happy the customers are with their transaction and overall experience with the company,

- satisfaction is as a judgment following a consumption experience - it is the consumer's judgment that a product provided a pleasurable level of consumption-related fulfillment.

\section{Monitoring and measuring}

The organization shall analyze and evaluate appropriate data and information arising from monitoring and measurement (Locher, 2008; Misztal, 2013; Mitra, 2016; Vogt, 2010). The results of analysis should be used to evaluate following activities (Wolniak, 2018):

- conformity of products and services;

- the degree of customer satisfaction;

- the performance and effectiveness of the quality management system;

- if planning has been implemented effectively;

- the effectiveness of actions taken to address risks and opportunities;

- the performance of external providers;

- the need for improvements to the quality management system.

Monitoring and measuring the performance of quality management system processes generate data. The data is analyzed and the results of analysis are used to evaluate the performance of processes. The planning of monitoring, measurement, analysis and evaluation actives are presented in the figure 1 .

The definitions of the terms used in the figure are as follows (ISO 9001:2015):

- Monitoring - a continuous inspection or observation of process performance or process output for a special purpose through a defined scope (e.g., with a sample size or over a period of time) and maintaining records of those observations.

- Measurement - the activity of delivering data to a method in order to define objectively a quantitative or qualitative measure and capturing a situation without any references to the significance.

- Analysis - a set of techniques for examining trends and tendencies of measurements of an output (process or product).

- Evaluation - the action of comparing a process or process output measurements against given criteria to determine the performance of the process or conformity of a process output. 


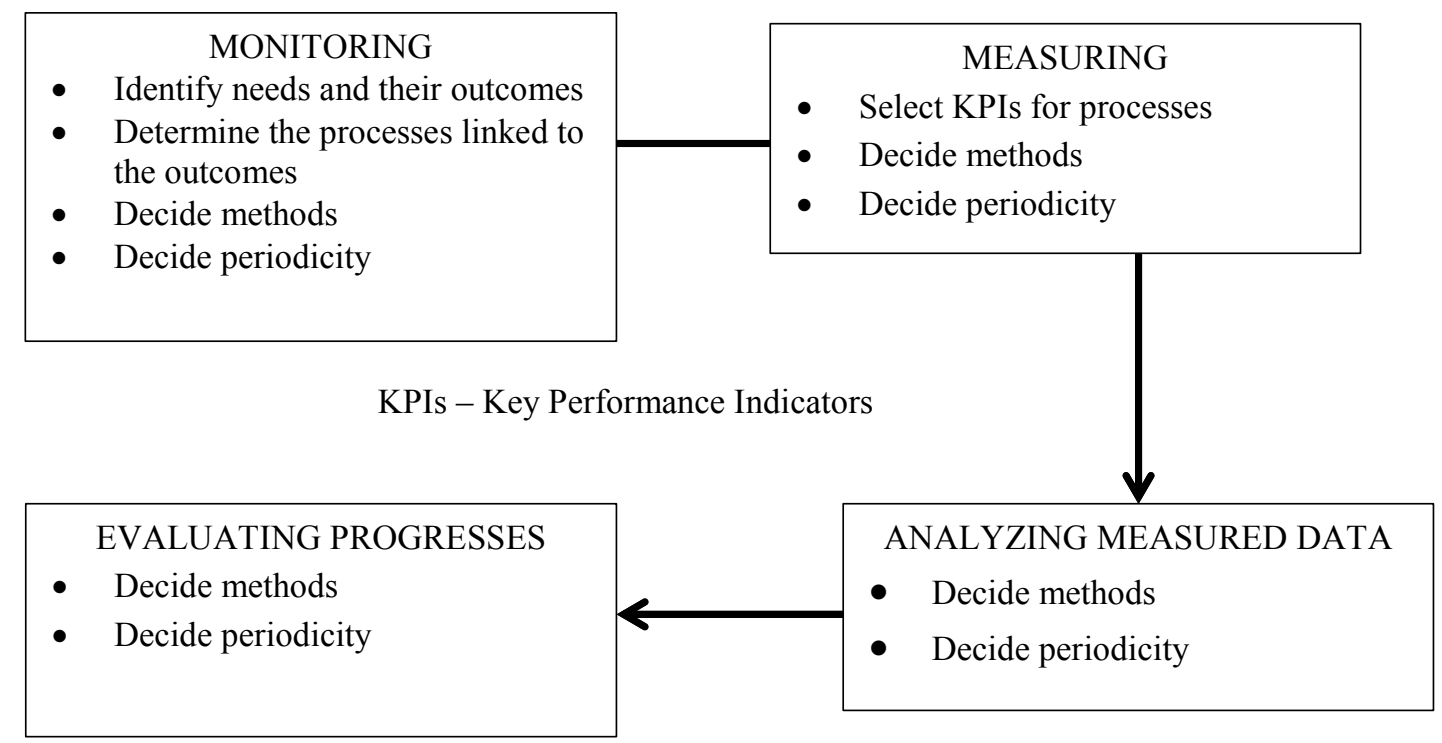

Figure 1. Planning of monitoring, measurement, analysis and evaluation. Source: (Natarajan, 2017).

The standard measure of functioning quality management systems are KPIs Key Performance Indicators. They are used in the organization to evaluate the effectiveness of a system. Monitoring and measuring KPIs present the performance of processes, operations and activities related to KPIs. When choosing the KPIs suitable for particular organization we should consider following points (Natarajan, 2017):

- The KPIs shall be related to the needs and expectations of interested parties, for example, KPIs may be part of the customer satisfaction or product performance objective.

- The KPIs shall be aligned with organizational strategies and drive the organization to achieve its quality objectives, for example, KPIs shall relate to quantity of nonconformities or level of customer satisfaction.

- KPIs should focus on a few high-value activities that reflect effectiveness of the process and that will deliver the most adequate data.

- KPIs shall provide critical information and data. In other words, changes that will be based on results of monitoring and measuring the KPI will induce changes and reactions on the organization.

- KPIs may be based on standard definitions, rules, and calculations, in order to enable a better analysis of the data they provide.

- For each KPI, an individual, a group, or a specific person shall be held responsible, for example, a process owner.

- KPIs shall be practical, which means it will be possible to draw conclusions from the data that are delivered. 
- KPIs should relate to the activities and operations of the quality management systems, and the relevant personnel may understand how they may influence them.

- The KPIs shall indicate points and events in a process that must be analyzed and evaluated.

- KPIs shall relate to the business activities and will make it possible for employees to know and identify when their intervention is needed when nonconformities are detected.

- Different KPIs should reinforce each other and not compete, contradict, or arouse conflicts with other KPIs.

The decisions on what is to be achieved and monitored should be derived from the risks and opportunities the organization face in successfully running the activities and improve further. Whatever we measure should help to (Purushothama, 2015):

- demonstrate the conformity of goods and services to requirements,

- evaluate the performance of processes,

- ensure the conformity and effectiveness of the quality management,

- system, and evaluate customer satisfaction.

Each monitoring and measuring activity should be conducted according to a defined method. The goal is to identify for each process, the parameters of output that affect its quality and determine the activities necessary to ensure valid results, activities that will ensure that the monitoring and measurement deliver results that can be analyzed and evaluated. When we monitor a process, the following issues should be referred (Abuhay, 2017):

- Identification of the processes or process outputs that must be monitored and measured.

- Identification of those parameters or outputs that may indicate how the process behaves.

- Identification of the function or the role responsible for conducting the activities of measurement (designated employees, a certain department, organizational unit, etc.).

- Definition of parameters for monitoring such as process conditions, interval, sampling rates, batch loads, and quantities.

- Description of the stages during the process where measurement activities shall be undertaken.

- Tools, equipment, or software required to perform or assist in the measurement.

- The activities and the use of techniques of measuring the process.

- Where and how the results must be documented.

- The criteria necessary for the evaluation of the results (the objectives).

- Action required in case nonconformities are detected. 


\section{Conclusion}

To achieve good performance evolution level in organization which have ISO 9001:2015 quality management system we need to implement appropriate monitoring system. Especially useful system is a system based on KPIs indicators which can measure particular activities of the organization. If we use good and broad system of KPIs indicator we can measure almost all aspect of functioning of quality management system. Then we could use those measure in the process of quality management system improvement. It lead to better performance of the system, better quality and better customer satisfaction.

\section{References}

1. Abuhav, I. (2017). ISO 9001:2015. A Complete Guide to Quality Management Systems, London: CRC Press.

2. Chen, C.K., Lee, J.D., Dahlgaard, J.J. (2016). A stepwise ISO-based TQM implementation approach using ISO 9001:2015, Management and Production Engineering Review, 4, 65-75.

3. Cholewicka-Goździk, K. (2016). Struktura normy ISO 9001:2015, podstawowe wymagania. Problemy Jakości, 1, 25-30.

4. Egonsson, E., Bayarsaikhan, K., Ting, Ly, T. (2013). After-sales services and customer relationship marketing: a multiple case study within Swedish heavy equipment machinery industry. Kalmar: Linneus University.

5. Gębczyńska, A., Wolniak, R. (2018). Process management level in local government. Philadelphia: CreativeSpace.

6. Hillson, D. (2001). Effective strategies for exploiting opportunities. Nashville: Tennessee.

7. Horodecka, A.M., Wolniak, R. (2015). Valutazione delle non conformita nell'esempio di un Azienda Italiana. In: J. Kaźmierczak (ed.), Systemy Wspomagania Inżynierii Produkcji. Review of problems and solutions (pp. 18-31).

8. Hoyle, D. (2009). ISO 9000. Quality systems handbook. Boston: Elsevier.

9. ISO 9001:2015. Quality management systems - Requirements.

10. Juszczak-Wiśniewska, A., Ligarski, M. (2015). Weryfikacja przydatności opracowanego narzędzia badawczego do analizy problemów w systemach zarządzania jakością. Zeszyty Naukowe Politechniki Ślaskiej. Seria Organizacji i Zarzadzanie, 80, 133-141.

11. Juszczak-Wiśniewska, A., Ligarski, M. (2015). Analysis of the causes the quantitative changes and trends in conferred ISO 9001 certificates in Poland Research based on the data from audits. Systemy Wspomagania w Inżynierii Produkcji, 1, 42-50. 
12. Juszczak-Wiśniewska, A., Ligarski, M. (2016). Akredytacja i certyfikacja systemów zarządzania jakością w placówkach medycznych w Polsce - wyniki badań. Systemy Wspomagania w Inżynierii Produkcji, 2, 163-171.

13. Łagowski, E., Żuchowski, J. (2016). Aktualizacje normy ISO $9001 \mathrm{w}$ aspekcie bieżących potrzeb gospodarczych. Problemy Jakości, 10, 15-22.

14. Ligarski, M. (2013). Problems examination in quality management system. Acta Technologica Agriculture, 4, 108-112.

15. Ligarski, M. (2014). Diagnoza systemu zarządzania jakością w polskich organizacjach. Problemy Jakości, 5, 14-22.

16. Locher, D. (2008). Value Stream Mapping for Lean Development. New York: Taylor \& Francis.

17. Łuczak, J., Wolniak, R. (2016). Integration of quality environment and safety management systems in a foundry. Metalurgija, 4, 843-845.

18. Misztal, A. (2013). When you need validation of the process? Machines Technology Materials, 11, 53-67.

19. Mitra, A. (2016). Fundamentals of Quality Control improvement. New Jersey: Wiley \& Sons.

20. Montgomery, D.C. (2009). Introduction to statistical quality control. New York: Wiley \& Sons.

21. Natarajan, D. (2015). Reliable design of electronic equipment: an engineering guide. Bangalore: Springer.

22. Natarajan, D. (2017). ISO 9001. Quality Management Systems. Bangalore: Springer.

23. Novakova, R., Cekanova, K., Paulikova, A. (2016). Integration management system new of requirements of ISO 9001:2015 and ISO 14001:2015 standards. Production Engineering Archives, 4, 35-40.

24. Olkiewicz, M., Wolniak, R., Grebski, E.M., Olkiewicz, A. (2019). Comparative analysis of the impact of the business incubator center on the economic sustainable development of regions in USA and Poland. Sustainability, 1, 1-22.

25. Pacana, A. (2014). Synteza i doskonalenie wdrażania systemów zarządzania jakościa zgodnych z ISO 9001 w małych i średnich organizacjach. Rzeszów: Oficyna Wydawnicza Politechniki Rzeszowskiej.

26. Pacana, A., Gazda, A., Bednárová, L. (2014). The impact of quality information on innovatory environment of the public administration. International Journal of Interdisciplinarity in Theory and Practice, 4, 25-26

27. Pacana, A., Ingaldi, M., Czajkowska, A. (2017). Projektowanie $i$ wdrażanie sformalizowanych systemów zarządzania. Rzeszów: Wydawnictwo Politechniki Rzeszowskiej. 
28. Pacana, A., Lew, G., Kulpa, W. (2017). Rating the quality of implementation of environmental management systems. Journal of Business \& Retail Management Research, 11(2), 165-169

29. Pacana, A., Stadnicka, D. (2006). Wdrażanie i audytowanie systemów zarzadzania jakościa zgodnych z norma ISO 9001:2000. Rzeszów: Oficyna Wydawnicza Politechniki Rzeszowskiej.

30. Pacana, A., Stadnicka, D. (2017). Nowoczesne systemy zarządzania jakościa zgodne z ISO 9001:2015. Rzeszów: Wydawnictwo Politechniki Rzeszowskiej.

31. Philips, A.W. (2015). ISO 9001:2015. Internal autits made easy. Tools, techniques and Step-by-Step Guidelines for Successful Internal Audit. Milwaukee: ASQ.

32. Poksińska, P., Dahlgaard, J.J., Marc, A. (2002). The state of ISO 9000 certification. A study of Swedish organizations. The TQM Magazine, 5, 297-305.

33. Purushothama, B. (2015). Implementing ISO 9001:2015. New Delhi: Woodhead Publishing India.

34. Stawiarska, E., Szwajca, D., Matusek, M., Wolniak, R. (2020). Wdrażanie rozwiazań przemystu $4.0 \mathrm{w}$ wybranych funkcjonalnych obszarach zarzadzania przedsiębiorstw branży motoryzacyjnej: próba diagnozy. Warszawa: CeDeWu.

35. Sułkowski, M., Wolniak, R. (2016). Przegląd stosowanych metod oceny skuteczności i efektywności organizacji zorientowanych na ciągłe doskonalenie. Zeszyty Naukowe Politechniki Śląskiej. Seria Organizacja i Zarzadzanie, 67, 63-74.

36. Sułkowski, M., Wolniak, R. (2018). Poziom wdrożenia instrumentów zarzadzania jakościa w przedsiębiorstwach branży obróbki metali. Częstochowa: Oficyna Wydawnicza Stowarzyszenia Menedżerów Produkcji i Jakości.

37. Szczucka-Lasota, B., Wolniak, R. (2018). Control plan and research supply as a tool in the process of decision making. Zeszyty Naukowe Politechniki Ślaskiej. Seria Organizacja i Zarzadzanie, 115, 439-447.

38. Szkiel, A. (2016). Orientacja na klienta w wymaganiach normy ISO 9001:2015. Marketing i Zarzadzanie, 3, 83-93.

39. Vogt, K. (2010). Human as an important factor in process production control. $7^{\text {th }}$ international BAAAM Baltic Conference.

40. Wolniak, R., Sułkowski, M. (2015). Motywy wdrażanie certyfikowanych Systemów Zarządzania Jakością. Problemy Jakości, 9, 4-9.

41. Wolniak, R, Skotnicka-Zasadzien, B. (2014). The use of value stream mapping to introduction of organizational innovation in industry. Metalurgija, 53(4), 709-713.

42. Wolniak, R. (2011). Parametryzacja kryteriów oceny poziomu dojrzałości systemu zarządzania jakością. Gliwice: Wydawnictwo Politechniki Śląskiej.

43. Wolniak, R. (2013). A typology of organizational cultures in terms of improvement of the quality management. Manager, 17(1), 7-21. 
44. Wolniak, R. (2013). Normalizacja zarządzania jakością a wymiary kulturowe kraju. Problemy Jakości, 9, 19-25.

45. Wolniak, R. (2013). Projakościowa typologia kultur organizacyjnych. Przeglad Organizacji, 3, 13-17.

46. Wolniak, R. (2013). W kierunku ISO 9001:2015. Problemy Jakości, 2, 10-14.

47. Wolniak, R. (2014). Korzyści doskonalenia systemów zarządzania jakością opartych o wymagania normy ISO 9001:2009. Problemy Jakości, 3, 20-25.

48. Wolniak, R. (2016). Kulturowe aspekty zarządzania jakością. Etyka biznesu i zrównoważony rozwój, Interdyscyplinarne studia teoretyczno-empiryczne, 1, 109-122.

49. Wolniak, R. (2016). Metoda QFD w zarządzaniu jakościa. Teoria i praktyka. Gliwice: Wydawnictwo Politechniki Śląskiej.

50. Wolniak, R. (2017). Analiza wskaźników nasycenia certyfikatami ISO 9001, ISO 14001 oraz ISO/TS 16949 oraz zależności pomiędzy nimi. Zeszyty Naukowe Politechniki Śląskiej. Seria Organizacji i Zarządzanie, 108, 421-430.

51. Wolniak, R. (2017). The Design Thinking method and its stages. Systemy Wspomagania Inżynierii Produkcji, 6, 247-255.

52. Wolniak, R. (2017). The use of constraint theory to improve organization of work. 4th International Multidisciplinary Scientific Conference on Social Sciences and Arts. SGEM 2017, 24-30 August 2017, Albena, Bulgaria. Conference proceedings. Book 1, Modern science. Vol. 5, Business and management. Sofia: STEF92 Technology, 10931100.

53. Wolniak, R. (2019). Context of the organization in ISO 9001:2015. Silesian University of Technology Scientific Papers. Organization and Management Series, 133, 121-136.

54. Wolniak, R. (2019). Downtime in the automotive industry production process - cause analysis. Quality, Innovation, Prosperity, 2, 101-118.

55. Wolniak, R. (2019). Leadership in ISO 9001:2015. Silesian University of Technology Scientific Papers. Organization and Management Series, 133, 137-150.

56. Wolniak, R. (2019). Support in ISO 9001:2015. Silesian University of Technology Scientific Papers. Organization and Management Series, 137, 247-261.

57. Wolniak, R. (2019). The level of maturity of quality management systems in Poland results of empirical research. Sustainability, 15, 1-17.

58. Wolniak, R. (2020). Design in ISO 9001:2015. Silesian University of Technology Scientific Papers. Organization and Management Series, 148, 769-781.

59. Wolniak, R. (2020). Operations in ISO 9001:2015. Silesian University of Technology Scientific Papers. Organization and Management Series, 148, 783-794.

60. Wolniak, R. (2020). Quantitative relations between the implementation of industry management systems in European Union countries. Silesian University of Technology Scientific Papers. Organization and Management Series, 142, 33-44. 
61. Wolniak, R., Sułkowski, M. (2015). Rozpowszechnienie stosowania Systemów Zarządzania Jakością w Europie na świecie - lata 2010-2012. Problemy Jakości, 5, 29-34.

62. Wolniak, R., Grebski, M.E., Skotnicka-Zasadzień, B. (2019). Comparative analysis of the level of satisfaction with the services received at the business incubators (Hazleton, PA, USA and Gliwice, Poland). Sustainability, 10, 1-22.

63. Wolniak, R., Hąbek, P. (2015). Quality management and corporate social responsibility. Systemy Wspomagania w Inżynierii Produkcji, 1, 139-149.

64. Wolniak, R., Skotnicka, B. (2011). Metody i narzędzia zarządzania jakościa - Teoria i praktyka, cz. 1. Gliwice: Wydawnictwo Naukowe Politechniki Śląskiej.

65. Wolniak, R., Skotnicka-Zasadzien, B. (2008). Wybrane metody badania satysfakcji klienta i oceny dostawców w organizacjach. Gliwice: Wydawnictwo Politechniki Śląskiej.

66. Wolniak, R., Skotnicka-Zasadzień, B. (2010). Zarządzanie jakościa dla inżynierów. Gliwice: Wydawnictwo Politechniki Śląskiej.

67. Wolniak, R., Skotnicka-Zasadzień, B., Zasadzień, M. (2019). Problems of the functioning of e-administration in the Silesian region of Poland from the perspective of a person with disabilities. Transylvanian Review of Public Administration, 57E, 137-155.

68. Wolniak, R., Sułkowski, M. (2016). The reasons for the implementation of quality management systems in organizations. Zeszyty Naukowe Politechniki Ślaskiej. Seria Organizacji i Zarządzanie, 92, 443-455.

69. Ząbek, J. (2016). ISO 9001:2015. Wybrane problemy zarządzania z perspektywy nowej normy. Ekonomika i Organizacja Przedsiębiorstwa, 2, 14-25.

70. Żemigała, M. (2017). Tendencje w badaniach nad normą ISO 9001. Problemy Jakości, 3, 2-9. 